\title{
Chemical Composition and In Vivo Nutrient Digestibility of Guinea and Merker Grass Hays ${ }^{1}$
}

\author{
J. A. Arroyo-Aguilú and J. A. Oporta-Téllez ${ }^{2}$ \\ ABSTRACT
}

\begin{abstract}
Chemical composition and in vivo nutrient digestibilities were determined in 30-, 45- and 60-day Guinea (Panicum maximum) and Merker or Napier (Pennisetum purpureum) grass hays. Four castrated male ruminants of each species: Holstein steers, native goat and sheep wethers, were utilized for the in vivo evaluations at each hay-age. Guinea hay showed a greater mean content than Merker hay in NDF (76.6 vs. $72.7 \%, \mathrm{P}<.01)$, ADF (47.1 vs. $45.0 \%, \mathrm{P}<.05)$, and $\mathrm{C}(35.2$ vs. $30.7 \%, \mathrm{P}<.01)$. Merker hay was higher than Guinea hay in CP $(9.1$ vs. $7.8 \%, \mathrm{P}<.01)$ and apparent digestion coefficients of $\mathrm{CP}(45.0$ vs. $38.5 \%, \mathrm{P}<.01), \mathrm{ADF}(52.0$ vs. $48.1 \%, \mathrm{P}<.01)$ and $\mathrm{H}(68.5$ vs. $61.4 \%, P<.01)$. These hays were similar in mean content of $L(7.8$ vs. $7.8 \%)$ and of H (Guinea, 29.5 vs. Merker, $27.7 \%$ ), as well as in digestion coefficients of NDF (Guinea, 55.5 vs. Merker, $58.1 \%$ ) and C (Guinea, 64.9 vs. Merker, $63.4 \%)$. Significant $(P<.01)$ differences were obtained only for DM and $C$ digestibilities between steers and goat wethers and between steers and sheep wethers. CP was the constituent that best predicted its digestible fraction. True NDS digestibility and bacterial and endogenous excretion values were $114.0 \%, 19.7 \% ; 76.0 \%, 11.0 \%$; and $76.0 \%, 11.0 \%$ for steers, and goat and sheep wethers, respectively.
\end{abstract}

\section{INTRODUCTION}

The nutritive value of forage grasses is characterized by chemical composition and digestibility, these factors being principally affected by plant species, age at harvest, and fertilization level. Grasses are the most economical sources of energy for ruminants, for they contain a high percentage of cellulose (C), lignin (L), and hemicellulose (H). As hay, forage grasses constitute a form of stored nutrients, necessary in periods of drought or feed shortage.

New methods for the determination of the chemical composition of forages were proposed by Van Soest (24), rendering more exact and precise results than the conventional Weende techniques (19).

The purpose of this study was to determine and compare the nutritive value of Guinea (Panicum maximum-PRPI 3622) and Merker or Napier (Pennisetum purpureum) grass hays at 30, 45 and 60 days of growth in steers, and goat and sheep wethers.

\section{MATERLALS AND METHODS}

The in vivo digestion trials were conducted at the University of Puerto Rico Agricultural Experiment Substation in Lajas during the years 1971

\footnotetext{
${ }^{1}$ Manuscript submitted to Editorial Board August 10, 1979.

${ }^{2}$ Nutritionist, Animal Industry Department, Agricultural Experiment Station, Mayagüez Campus, University of Puerto Rico, Río Piedras, P.R., and Professor, Escuela Nacional de Agricultura y Ganadería, Managua, Nicaragua, respectively.
} 
to 1973. The Lajas Substation is located on the southwestern coast of Puerto Rico at lat. $18^{\circ} \mathrm{N}$. and long. $67^{\circ} \mathrm{W}$. The area is characterized as semiarid, with mean rainfall of $1120 \mathrm{~mm}$. Maximum and minimum temperatures are $31.1^{\circ} \mathrm{C}$ and $18.3^{\circ} \mathrm{C}$, respectively. The soil is Fraternidad clay, an Udic Chromusterts.

Guinea and Merker grasses were grown in pure stands of .4-ha plots. The plots were fertilized at the rate of $4480 \mathrm{~kg} / \mathrm{ha} / \mathrm{yr}$ with a $15-5-10$ analysis. The grasses were harvested by hand at 30, 45 and 60 days of growth and sun-dried for approximately 2 days. The hays, chopped into 3- to 6-cm pieces, were offered to four castrated male ruminants of each species: 1-year-old Holstein steers, 11/2-year-old native goat and sheep wethers in individual digestion stalls, for a total of 24 digestion trials.

The trials consisted of a 14-day preliminary feeding period and a 7-day collection period. During the preliminary period, the hays were offered ad libitum. Hays offered during the collection period were $90 \%$ of full feed established during the preliminary period.

The hays, offered and refused (orts), and the feces were weighed and sampled daily. Feces were weighed two times a day, at 7 a.m. and at 3 p.m., during the collection period. Samples were oven-dried at $60^{\circ} \mathrm{C}$ for 2 or 3 days and ground in a Wiley mill through a 1-mm screen. Seven-day composite samples were prepared from the hays, orts and feces of each animal.

All samples were analyzed chemically by the AOAC (6) methods for dry matter (DM) and crude protein (CP) and by the Goering and Van Soest (15) fiber fractionation techniques for cell wall or neutral-detergent fiber (NDF), acid-detergent fiber (ADF), L, C, and silica ( $\mathrm{Si}$ ) contents. Neutral-detergent solubles (NDS) was calculated as the difference between $100 \%$ and NDF. H was determined as the difference between NDF and ADF. Apparent digestion coefficients for all nutrients were calculated.

The results were statistically analyzed, according to a $2 \times 3 \times 4$ factorial design by simple and multiple regressions and correlations and the $t$ test according to Snedecor and Cochran (20).

\section{RESULTS AND DISCUSSION}

\section{CHEMICAL COMPOSITION}

Table 1 shows data on chemical composition of 30-, 45- and 60-day Guinea and Merker hays. Guinea hay was higher in NDF and $\mathrm{C}(\mathrm{P}<.01)$ and in $\mathrm{ADF}(\mathrm{P}<.05)$ contents but lower in $\mathrm{CP}(\mathrm{P}<.01)$ contents than Merker hay. Similar results were obtained by Arroyo-Aguilú et al. (5) between Guinea and Merker grasses in NDF, ADF, C and CP contents. No significant differences in DM, H, L and Si contents were observed between hays. However, Guinea hay exhibited a higher $\mathrm{H}$ content than 
Merker hay and DM, L and Si contents were similar in Guinea and Merker.

$\mathrm{CP}$ content decreased in hays between 30 and 45 days $(\mathrm{P}<.01), 30$ and 60 days $(\mathrm{P}<.01)$ and 45 and 60 days $(\mathrm{P}<.05)$. Among hay ages, there were significant differences $(\mathrm{P}<.01)$ in $\mathrm{NDF}, \mathrm{L}, \mathrm{C}$ and Si contents, but $\mathrm{DM}, \mathrm{ADF}$ and $\mathrm{H}$ contents did not vary significantly; however, there was a definite trend for $\mathrm{ADF}$ and $\mathrm{H}$ to increase. At 60 days of growth, NDF, $\mathrm{ADF}, \mathrm{H}, \mathrm{L}$ and $\mathrm{C}$ contents were highest but $\mathrm{CP}$ and $\mathrm{Si}$ contents were lowest. Gutiérrez-Vargas et al. (16) also reported reduction of Si content with advancing maturity from 30 to 60 days of growth in Pangola (Digitaria decumbens) and Star (Cynodon nlemfuensis) hays. Coward-

TABLE 1.-Chemical composition of 30-, 45- and 60-day Guinea and Merker hays

\begin{tabular}{|c|c|c|c|c|c|c|c|c|c|}
\hline Hay & Age & $\mathrm{DM}^{1}$ & $\mathrm{CP}$ & NDF & $\mathrm{ADF}$ & $\mathrm{H}$ & $\mathrm{L}$ & $\mathrm{C}$ & $\mathrm{Si}$ \\
\hline & Days & & & & & 6 & & & \\
\hline \multirow[t]{3}{*}{ Guinea } & 30 & 89.2 & 8.8 & 72.3 & 46.4 & 25.9 & 7.3 & 33.7 & 6.7 \\
\hline & 45 & 89.0 & 7.5 & 79.0 & 46.9 & 32.1 & 7.3 & 34.7 & 5.2 \\
\hline & 60 & 89.5 & 7.0 & 78.6 & 48.0 & 30.6 & 8.8 & 37.2 & 3.6 \\
\hline Mean & & $89.2 a^{2}$ & $7.8 \mathrm{a}$ & $76.6 \mathrm{a}$ & $47.1 \mathrm{a}$ & $29.5 \mathrm{a}$ & $7.8 \mathrm{a}$ & $35.2 \mathrm{a}$ & $5.2 \mathrm{a}$ \\
\hline \multirow[t]{3}{*}{ Merker } & 30 & 89.8 & 9.8 & 69.7 & 43.3 & 26.4 & 7.1 & 27.5 & 6.0 \\
\hline & 45 & 89.2 & 9.1 & 71.8 & 46.3 & 25.5 & 7.9 & 31.5 & 4.9 \\
\hline & 60 & 89.1 & 8.4 & 76.6 & 45.5 & 31.1 & 8.4 & 33.1 & 4.5 \\
\hline Mean & & $89.4 \mathrm{a}$ & $9.1 \mathrm{~b}$ & $72.7 \mathrm{~b}$ & $45.0 \mathrm{~b}$ & $27.7 \mathrm{a}$ & $7.8 \mathrm{a}$ & $30.7 \mathrm{~b}$ & $5.1 \mathrm{a}$ \\
\hline \multicolumn{10}{|l|}{ Guinea and } \\
\hline \multirow[t]{3}{*}{ Merker } & 30 & 89.5 a & $9.3 \mathrm{a}$ & $71.0 \mathrm{a}$ & $44.8 \mathrm{a}$ & $26.2 \mathrm{a}$ & $7.2 \mathrm{a}$ & $30.6 \mathrm{a}$ & $6.3 \mathrm{a}$ \\
\hline & 45 & 89.1 a & $8.3 \mathrm{~b}$ & $75.4 \mathrm{~b}$ & $46.6 \mathrm{a}$ & $28.8 \mathrm{a}$ & $7.6 \mathrm{~b}$ & $33.1 \mathrm{~b}$ & $5.1 \mathrm{~b}$ \\
\hline & 60 & $89.3 \mathrm{a}$ & $7.7 \mathrm{c}$ & $77.6 \mathrm{c}$ & $46.8 \mathrm{a}$ & $30.8 \mathrm{a}$ & $8.6 \mathrm{c}$ & $35.2 \mathrm{c}$ & $4.0 \mathrm{c}$ \\
\hline \multicolumn{10}{|l|}{ Grand } \\
\hline Mean & & 89.3 & 8.4 & 74.7 & 46.1 & 28.6 & 7.8 & 33.0 & 5.1 \\
\hline
\end{tabular}

' DM, dry matter, CP, crude protein; NDF, neutral-detergent fiber; ADF, acid-detergent fiber; $\mathrm{H}$, hemicellulose; L, lignin; C, cellulose; $\mathrm{Si}$, silica.

${ }^{2}$ Mean values in the same category with one or more letters in common do not differ significantly at the $5 \%$ level.

Lord et al. (10) reported that the largest increase in NDF, ADF, L and C contents occurs between 30 - and 60-day growth stages, probably due to the high environmental temperature and high transpiration causing early onset of lignification of cell walls in tropical grasses. Dirven and Deinum (13) indicated that the continuous stem elongation in subtropical and tropical grasses is greatly stimulated by higher temperature, causing a decline in leaf percentage and a sharp decrease of stem digestibility, especially in an old stage.

\section{DIGESTION COEFFICIENTS}

Table 2 shows data on apparent nutrient digestibility of 30-, 45- and 60-day Guinea and Merker hays, determined with steers and goat and 
sheep wethers. Among hays, significant differences $(\mathrm{P}<.01)$ were obtained only in $\mathrm{CP}, \mathrm{ADF}, \mathrm{H}$ and $\mathrm{L}$ digestibilities, Merker hay being superior to Guinea hay. This is probably due to the lower cell wall and higher CP contents in Merker hay. Although not significant, DM and NDF digestibilities were higher while $\mathrm{C}$ and $\mathrm{Si}$ digestibilities were lower in Merker hay.

Significant differences $(\mathrm{P}<.01)$ between 30 - and 45-day and 30- and 60 -day grasses were obtained in DM, CP, ADF, C and Si digestibilities. Differences between 30 - and 45 -day grasses were also significant $(\mathrm{P}<.01)$ for $\mathrm{L}$ digestibility. Significant differences $(\mathrm{P}<.01)$ for ADF and $\mathrm{L}$ diges-

TABLE 2.-In vivo nutrient digestibility of 30-, 45- and 60-day Guinea and Merker hays

\begin{tabular}{|c|c|c|c|c|c|c|c|c|}
\hline Variable & $\mathrm{DM}^{1}$ & $\mathrm{CP}$ & NDF & $\mathrm{ADF}$ & $\mathrm{H}$ & $\mathrm{L}$ & C & $\mathrm{Si}$ \\
\hline & \multicolumn{8}{|c|}{$\%$} \\
\hline \multicolumn{9}{|l|}{ Hay } \\
\hline Guinea & $48.4 \mathrm{a}^{2}$ & $38.5 \mathrm{a}$ & $55.5 \mathrm{a}$ & $48.1 \mathrm{a}$ & $61.4 \mathrm{a}$ & $24.0 \mathrm{a}$ & $64.9 \mathrm{a}$ & $-13.5 \mathrm{a}$ \\
\hline Merker & $51.9 \mathrm{a}$ & $45.0 \mathrm{~b}$ & $58.1 \mathrm{a}$ & $52.0 \mathrm{~b}$ & $68.5 \mathrm{~b}$ & $34.9 \mathrm{~b}$ & $63.4 \mathrm{a}$ & $-13.8 a$ \\
\hline \multicolumn{9}{|l|}{ Age (days) } \\
\hline 30 & $54.6 \mathrm{a}$ & $50.5 \mathrm{a}$ & $58.8 \mathrm{a}$ & $52.5 \mathrm{a}$ & $66.7 \mathrm{a}$ & $35.6 \mathrm{a}$ & $65.8 \mathrm{a}$ & $-0.3 a$ \\
\hline 45 & $47.6 \mathrm{~b}$ & $37.8 \mathrm{~b}$ & $54.6 \mathrm{a}$ & $47.4 \mathrm{~b}$ & $64.5 \mathrm{a}$ & $20.8 \mathrm{~b}$ & $63.2 \mathrm{~b}$ & $-18.9 b$ \\
\hline 60 & $48.2 \mathrm{~b}$ & $37.1 \mathrm{~b}$ & $57.0 \mathrm{a}$ & $50.3 \mathrm{c}$ & $63.6 \mathrm{a}$ & $32.0 \mathrm{a}$ & $63.4 \mathrm{~b}$ & $-21.5 b$ \\
\hline \multicolumn{9}{|l|}{ Ruminant } \\
\hline $\begin{array}{l}\text { Steers } \\
\text { Goat }\end{array}$ & $52.9 \mathrm{a}$ & $42.6 \mathrm{a}$ & $59.0 \mathrm{a}$ & $51.0 \mathrm{a}$ & $66.7 \mathrm{a}$ & $29.8 \mathrm{a}$ & $67.2 \mathrm{a}$ & $-11.0 \mathrm{a}$ \\
\hline $\begin{array}{l}\text { wethers } \\
\text { Sheep }\end{array}$ & $47.8 \mathrm{~b}$ & $40.1 \mathrm{a}$ & $55.9 \mathrm{a}$ & $49.7 \mathrm{a}$ & $63.1 \mathrm{a}$ & $29.5 \mathrm{a}$ & $64.0 \mathrm{~b}$ & $-15.5 a$ \\
\hline $\begin{array}{l}\text { wethers } \\
\text { Mean }\end{array}$ & $\begin{array}{l}49.7 \mathrm{~b} \\
50.1\end{array}$ & $\begin{array}{l}42.6 a \\
41.8 \\
\end{array}$ & $\begin{array}{l}55.5 \mathrm{a} \\
56.8 \\
\end{array}$ & $\begin{array}{l}49.6 \mathrm{a} \\
50.1 \\
\end{array}$ & $\begin{array}{l}65.0 \mathrm{a} \\
65.0\end{array}$ & $\begin{array}{l}29.0 \mathrm{a} \\
29.5\end{array}$ & $\begin{array}{l}61.2 \mathrm{~b} \\
64.1\end{array}$ & $\begin{array}{l}-14.5 \mathrm{a} \\
-13.7 \\
\end{array}$ \\
\hline
\end{tabular}

' DM, dry matter; CP, crude protein; NDF, neutral-detergent fiber; ADF, acid-detergent fiber; $\mathrm{H}$, hemicellulose; L, lignin; $\mathrm{C}$, cellulose; $\mathrm{Si}$, silica.

${ }^{2}$ Mean values in the same category with one or more letters in common do not differ significantly at the $5 \%$ level.

tibilities were obtained between 45- and 60-day grasses. Highest digestion coefficients were obtained for all nutrients at the 30-day growth stage. At older or more mature growth stages $\mathrm{CP}$ content was reduced, while cell wall contents increased, with a reduction in the digestibility of both fractions.

According to Ulyatt (21), straws, hays, native pastures and herbages from tropical and arid regions fall below 70\% apparent digestibility. These forages have considerable bulk and a high proportion of their DM is not digestible. Ruminants consume forages to a certain distension of their rumen. The rumen load is reduced to the point where hunger recurs, depending on rate of breakdown of feeds and on rate of passage of undigested residues. As a result, digestibility involves rumen fill, rate of 
breakdown and rate of passage. Conrad et al. (9) considered that the intake of forages of lower than $67 \%$ digestibility was governed by physical means while forage intake greater than $67 \%$ digestibility was regulated by physiological mechanisms.

High L digestibilities of 24.0 and $34.9 \%$ were obtained from Guinea and Merker hays, respectively. Jones et al. (17) obtained mean L digestibilities of 41.0 and $38.0 \%$ in alfalfa (Medicago sativa) hays with goat and sheep wethers, respectively. Combellas et al. (8) reported a $\mathrm{L}$ digestibility range from -7.4 to $63.3 \%$ in tropical grasses. This range tends to demonstrate that $\mathrm{L}$ may not be an inert substance in the ruminant digestive process. On the other hand, Gutiérrez-Vargas et al. (16) obtained mean L digestibility values of 1.1 and $-3.2 \%$ for Pangola and Star hays, respectively.

Negative Si digestibilities of -13.5 and $-13.8 \%$ and of $-0.3,-18.9$ and $-21.5 \%$ were obtained for Guinea and Merker hays and for 30-, 45- and 60-day hays, respectively. Combellas et al. (8) obtained a mean $\mathrm{Si}$ digestibility of $-40.2 \%$ in 23 tropical grasses. Gutiérrez-Vargas et al. (16) reported Si digestibilities of -6.2 and $-13.9 \%$ in Pangola and Star hays, respectively. These researchers suggested that possibly part of the contaminant Si was lost during the sampling and/or analysis. Si was not lost in the feces, thus resulting in a Si fraction greater than in the hays.

Significant $(\mathrm{P}<.01)$ differences were obtained among ruminant species only for DM and C digestibilities between steers and goat wethers, and between steers and sheep wethers. In all cases, steers provided higher digestibilities than goat or sheep wethers. Devendra and Burns (12) expressed that differences in DM digestibility between cattle and goat or sheep wethers could be due to differences in their ability to digest fiber. Cattle digested a greater proportion of NDF and ADF than did sheep wethers. This may be a secondary effect caused by differences between cattle and sheep wethers in their ability to recycle nutrients to the rumen. Baumgardt et al. (7) and Jones et al. (17) demonstrated that steers utilize $\mathrm{C}$ better than goats and $\mathrm{L}$ better than goat and sheep wethers, respectively. In Zambia, Gihad (14) observed that goat wethers were as reliable as sheep wethers in the prediction of the nutritive value of Hyparrhenia hay. In Nigeria, Ademosun (1) reported that crude fiber and energy digestibilities of Elephant or Napier hay by goat and sheep wethers were not significant.

\section{REGRESSIONS BETWEEN TOTAL AND DIGESTIBLE NUTRIENTS}

Table 3 presents simple regression equations and correlations to estimate digestible nutrients from total nutrients in steers, and goat and sheep wethers consuming Guinea and Merker hays. The highest correlations $(\mathrm{P}<.01)$ were obtained for $\mathrm{CP}$ in steers, goat wethers and sheep 
TABLE 3.-Regression equations of form $\mathrm{Y}=\mathrm{a}+\mathrm{bX}$ for estimating percent digestible nutrients (Y) from percent total nutrients (X) in Guinea and Merker hays

\begin{tabular}{|c|c|c|c|c|}
\hline Nutrient & Intercept & $\begin{array}{l}\text { Coefficient of } \\
\text { regression }\end{array}$ & $\begin{array}{l}\text { Coefficient of } \\
\text { correlation }\end{array}$ & $\begin{array}{l}\text { Standard error } \\
\text { of estimate }\end{array}$ \\
\hline & $a$ & $b$ & $r$ & \\
\hline \multicolumn{5}{|c|}{ Steers } \\
\hline $\mathrm{CP}^{1}$ & -3.60 & +.87 & $+.95^{* * 2}$ & 0.43 \\
\hline NDS & -19.66 & +1.14 & $+.82^{* *}$ & 3.41 \\
\hline NDF & +13.90 & +.40 & +.37 & 4.36 \\
\hline $\mathrm{ADF}$ & -6.81 & +.66 & $+.79^{* *}$ & 2.68 \\
\hline $\mathrm{H}$ & -10.10 & +1.04 & $+.85^{* *}$ & 3.40 \\
\hline $\mathrm{C}$ & -4.67 & -.84 & $+.84^{* *}$ & 2.18 \\
\hline $\mathrm{L}$ & +.26 & +.35 & +.20 & 1.16 \\
\hline $\mathrm{Si}$ & -2.97 & +.48 & $+.62^{* *}$ & 0.79 \\
\hline \multicolumn{5}{|c|}{ Goat wethers } \\
\hline $\mathrm{CP}$ & -5.09 & +1.02 & $+.92^{* *}$ & 0.60 \\
\hline NDS & -11.00 & +.76 & $+.84^{* *}$ & 4.52 \\
\hline NDF & +7.86 & +.45 & +.34 & 5.45 \\
\hline $\mathrm{ADF}$ & +18.66 & +.09 & +.11 & 2.93 \\
\hline $\mathrm{H}$ & -6.92 & +89 & $+.88 * *$ & 2.93 \\
\hline $\mathrm{C}$ & -.59 & -.63 & $+.67^{* *}$ & 2.67 \\
\hline $\mathrm{L}$ & -5.49 & +1.02 & $+.63^{* *}$ & 1.26 \\
\hline $\mathrm{Si}$ & -2.50 & +.40 & $+.49^{*}$ & 0.85 \\
\hline \multicolumn{5}{|c|}{ Sheep wethers } \\
\hline $\mathrm{CP}$ & -4.02 & +.92 & $+.93^{* *}$ & 0.54 \\
\hline NDS & -10.95 & +.76 & $+.83^{* *}$ & 2.62 \\
\hline NDF & +19.24 & +.30 & +.27 & 5.24 \\
\hline $\mathrm{ADF}$ & +10.48 & +.27 & +.29 & 3.17 \\
\hline $\mathrm{H}$ & +22.43 & +.03 & +.01 & 4.63 \\
\hline $\mathrm{C}$ & -4.89 & +.76 & $+.71^{* *}$ & 2.77 \\
\hline $\mathrm{L}$ & -2.67 & +.63 & $+.46^{* 3}$ & 1.17 \\
\hline $\mathrm{Si}$ & -.99 & -.02 & +.01 & 2.07 \\
\hline
\end{tabular}

${ }^{1} \mathrm{CP}$, crude protein; NDS, neutral-detergent solubles; NDF, neutral-detergent fiber; ADF, acid-detergent fiber; $\mathrm{H}$, hemicellulose; L, lignin; c, cellulose; $\mathrm{Si}$, silica.

${ }^{2}$ Significant at the 1 -percent level.

${ }^{3}$ Significant at the 5 -percent level.

wethers; for $\mathrm{H}$ in steers and goat wethers; for $\mathrm{C}$ in steers and for NDS in steers, and goat and sheep wethers. Similar regression equations were reported by Arroyo-Aguilú and Rivera-Brenes (4) and Arroyo-Aguilú and Evans (2) for $\mathrm{CP}$ and $\mathrm{H}$ in steers, respectively. The regression equations for $\mathrm{CP}$ in steers and wethers were very similar, thus showing the lowest standard errors of estimate. The CP equation, developed for goat wethers, was also significant $(\mathrm{P}<.01)$ and similar to that of steers and sheep wethers. As a result, the relation of $\mathrm{CP}$ to digestible protein (DP), expressed by its regression and correlation, tends to present the equation as the best predictor of DP. 
TABLE 4.-Estimated true and apparent digestibilities from summative equalions and in vivo dry matter digestibilities from data of 24 digestion trials with steers, and goat and sheep wethers

\begin{tabular}{|c|c|c|c|c|c|}
\hline & $\mathrm{DM}^{1}$ & $\mathrm{DC}$ & \multicolumn{2}{|l|}{$\mathrm{DN}$} & \multirow[t]{2}{*}{ DMD } \\
\hline & & & $\%$ & & \\
\hline \multicolumn{6}{|c|}{ Steers } \\
\hline NDS & 24.9 & 114.0 & 28.4 & 28.4 & \\
\hline NDF & 75.1 & 59.0 & 44.3 & & \\
\hline $\mathrm{H}$ & 29.6 & 66.7 & & 19.7 & \\
\hline $\mathrm{C}$ & 33.4 & 67.2 & 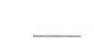 & $\underline{22.4}$ & \\
\hline TD & & & 72.7 & 70.5 & \\
\hline $\mathrm{BEE}$ & & & $-\underline{19.7}$ & $-\underline{19.7}$ & \\
\hline $\mathrm{AD}$ & & & 53.0 & 50.8 & 52.9 \\
\hline \multicolumn{6}{|c|}{ Goat wethers } \\
\hline NDS & 25.6 & 76.0 & 19.5 & 19.5 & \\
\hline NDF & 74.4 & 55.9 & 41.6 & & \\
\hline $\mathrm{H}$ & 28.0 & 63.1 & & 17.7 & \\
\hline $\mathrm{C}$ & 32.6 & 64.0 & 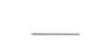 & $\underline{20.9}$ & \\
\hline TD & & & 61.1 & 58.1 & \\
\hline BEE & & & $-\underline{11.0}$ & $-\underline{11.0}$ & \\
\hline $\mathrm{AD}$ & & & 50.1 & 47.1 & 47.8 \\
\hline \multicolumn{6}{|c|}{ Sheep wethers } \\
\hline NDS & 25.5 & 76.0 & 19.4 & 19.4 & \\
\hline $\mathrm{NDF}$ & 74.5 & 55.5 & 41.4 & & \\
\hline $\mathrm{H}$ & 28.2 & 65.0 & & 18.3 & \\
\hline $\mathrm{C}$ & 32.8 & 61.2 & - & $\underline{20.1}$ & \\
\hline TD & & & 60.8 & 57.8 & \\
\hline $\mathrm{BEE}$ & & & $-\underline{11.0}$ & $-\underline{11.0}$ & \\
\hline $\mathrm{AD}$ & & & 49.8 & 46.8 & 49.7 \\
\hline
\end{tabular}

${ }^{1} \mathrm{DM}$, dry matter; DC, digestibility coefficient; DN, digestible nutrient; DMD, dry matter digestibility; NDS, neutral-detergent solubles; NDF, neutral-detergent fiber; $\mathrm{H}$, hemicellulose; C, cellulose; TD, true digestibility; $\mathrm{BEE}$, bacterial and endogenous excretion; $\mathrm{AD}$, apparent digestibilty.

\section{ESTIMATED DIGESTIBILITY}

Table 4 shows summative equations for calculating true and apparent digestibility of steers, sheep wethers and goat wethers.

Van Soest $(23,24)$ determined that NDS have a digestibility of $98 \%$ and apply to forages as well as to concentrates in monogastrics and ruminants. NDS are essentially available; however, their digestibility appears incomplete due to the excretion of non-cell-wall matter, principally of bacterial and endogenous origin. The bacterial and endogenous excretion (BEE) of the DM amounts to an average of $12.9 \%$ of intake, and this value represents the difference between the true and the appar- 
ent digestibility of DM. This was demonstrated by Van Soest (24), by relating total and digestible NDS contents with the Lucas et al. (18) test. The regression coefficient, $b$, is an estimate of true NDS digestibility and the regression constant, $a$, represents BEE.

In this study, true NDS digestibility and BEE values (table 4) were $114.0 \%, 19.7 \% ; 76.0 \%, 11.0 \%$; and $76.0 \%, 11.0 \%$ for steers, and goat and sheep wethers, respectively. In the steers, but not in goat or sheep wethers, NDS contents were readily digested. With sheep wethers in Venezuela, Combellas et al. (8) obtained a similar digestion coefficient greater than $100 \%$ and consequently, a higher BEE fraction, than that obtained in this study.

Deinum and Van Soest (11), in Holland, assumed that the BEE fraction is proportionately related to the amount of substrate, but it appears from their samples that the BEE fraction is negatively related to the NDS content. They suggested that this is only possible if, at higher temperatures of NDS contents, a larger portion of this fraction is transported so fast to the abomasum that it escapes from the microflora. This may explain the fact that the calculated true NDS digestibility for Dutch grasses (11) was $118.0 \%$, with a BEE fraction of $23.0 \%$. A similar situation occurred with tropical grasses in this study.

Goat and sheep wethers exhibited identical NDS digestibility and BEE values. The lower NDS digestibility in goat and sheep wethers could be attributed possibly to the lower intakes due to the coarseness of the hay. Arroyo-Aguilú and Gutiérrez-Vargas (3) reported a higher NDS digestibility for goat wethers than for steers, although both hays were highly digestible. In this study, BEE values were higher in steers than in goat or sheep wethers. Van Soest (22) has given evidence that as intake increases, the BEE also increase and are not, as is usually considered, constant.

In vivo apparent DM digestibility values for steers (52.9\%) and for sheep wethers $(49.7 \%)$ are in close agreement with values determined by the summative equation (NDS) for steers (53.0\%) and sheep wethers (49.8\%). The goat wethers' true digestibility value for $\mathrm{H}$ and $\mathrm{C}$ substitution $(47.1 \%)$ is in close agreement with the in vivo apparent DM digestibility (47.8\%). H and C substitution values for steers and sheep wethers and NDF value for goat wethers were lower and higher, respectively, than comparative values. As indicated by Deinum and Van Soest (11), comparative values depend upon NDF and NDS digestibility and upon BEE.

Merker grass has a higher chemical composition than Guinea grass; significant differences between ruminant digestibilities are detectable only for DM and C. The summative equations developed for apparent digestibility compare favorably with in vivo DM digestibilities and CP is the constituent that best predicts its digestible fraction. 


\section{RESUMEN}

Los pastos Guinea (Panicum maximum) y Merker o Napier (Pennisetum purpureum), cosechados a 30, 45 y 60 dias de edad y henificados, fueron evaluados en pruebas de digestibilidad con 4 rumiantes castrados de tres especies: novillos Holstein, cabros y carneros nativos. Los pastos se abonaron a razón de $4480 \mathrm{~kg} /$ ha y año con un análisis 15-5-10, se henificaron por 2 días y se cortaron en trozos de 3 a $6 \mathrm{~cm}$. Cada período experimental duró 21 días, de los cuales los primeros 14 días constituyeron un período preliminar de adaptación y los restantes 7 días uno de colección total. Cada heno se ofreció a un nivel de consumo de $90 \%$ del determinado en el período preliminar. Los henos, ofrecidos y rechazados, y las heces, se pesaron diariamente. Las muestras representativas tomadas diariamente se analizaron para materia seca (DM), proteína bruta (CP), fibra neutrodetergente (NDF), fibra ácidodetergente (ADF), celulosa (C), lignina (L) y sílice (Si). La diferencia entre 100\% y NDF es la fracción soluble neutrodetergente (NDS). La H se determinó como la diferencia entre la NDF y la ADF. Se calcularon los coeficientes de digestibilidad aparente para cada heno en cada rumiante. El heno de Guinea arrojó un contenido medio más elevado que el heno de Merker en: NDF (76.6 vs $72.7 \%, P<.01)$, ADF (47.1 vs $45.0 \%, P<.5)$ y $\mathrm{C}(35.2$ vs $30.7 \%, P<.01$ ). El heno de Merker fue significativamente más rico que el de Guinea en: CP (9.1 vs $7.8 \%, P<.01)$ y más elevado en los coeficientes de digestibilidad aparente de CP $(45.0$ vs $38.5 \%, P<.01)$, ADF (52.0 vs $48.1 \%, \mathrm{P}<.01$ ) y H (68.5 vs $51.4 \%, \mathrm{P}<.01)$. Ambos henos fueron similares en el contenido medio de $\mathrm{L}$ (7.8 vs $7.8 \%$ ) y de $\mathrm{H}$ (Guinea, 29.5 vs Merker, 27.7\%), como también en los coeficientes de digestibilidad de NDF (Guinea, 55.5 vs Merker, $58.1 \%$ ) y de C (Guinea, 64.9 vs Merker, 63.4\%). Se obtuvieron diferencias significativas ( $P<.01$ ) solamente para las digestibilidades de la MS y de la C entre novillos y cabros castrados y entre novillos y carneros. La CP fue el criterio que mejor predijo su fracción digestible. Los valores de digestibilidad real de los NDS y de la excreción bacterial y endógena fueron $114.0 \%, 19.7 \%$; $76.0 \%, 11.0 \%$; y $76.0 \%, 11.0 \%$ para novillos, cabros castrados y carneros, respectivamente.

\section{LITERATURE CITED}

1. Ademosum, A. A., 1969. Nutritive evaluation of Nigerian forages. 1. Digestibility of Pennisetum purpureum by sheep and goats, Niger. Agri. J. 7 (1): 19-26.

2. Arroyo-Aguilú, J. A. and Evans, J. L., 1972. Nutrient digestibility of lower-fiber rations in the ruminant animal, J. Dairy Sci. 55: 1266-74.

3. - and Gutiérrez-Vargas, R., 1979. Interrelaciones entre consumo, componentes químicos y digestibilidad de henos tropicales, ALPA Mem. (In press).

4. - and Rivera-Brenes, L., 1965. Relationship between the percentages of crude protein and apparently digestible protein in some forages of Puerto Rico, J. Agri. Univ. P.R. 49: (1): 145-8. 
5. - - Tessema,sS., McDowell, R. E., Van Soest, P. J., Ramírez, A., and Randel, P. F., 1975. Chemical composition and in vitro digestibility of five heavily fertilized tropical grasses in Puerto Rico, J. Agri. Univ. P.R. 59 (3): 186-98.

6. Association of Official Analytical Chemists, 1975. Official Methods of Analysis, 12th ed, Washington, D.C.

7. Baumgardt, B. R., Byer, W. J., Jumah, H. F., and Krueger, C. R., 1964. Digestion in the steer, goat and artificial rumen as measures of forage nutritive value, J. Dairy Sci. 47: $160-4$.

8. Combellas, J., González, J. E., and Parra, R. R., 1971. Composición y valor nutritivo de forrajes producidos ên el trópico. I. Digestibilidad aparente y verdadera de las fracciones químicas, Agron. Trop. 21: 483-94.

9. Conrad, H. R., Pratt, A. D., and Hibbs, J. W., 1964. Regulation of feed intake in dairy cows, I. Change in importance of physical and physiological factors with increasing digestibility, J. Dairy Sci. 47: 54-62.

10. Coward-Lord, J., Arroyo-Aguilú, J. A., and García-Molinari, O., 1974. Fibrous carbohydrate fractions and in vitro true and apparent digestibility of 10 tropical forage grasses, J. Agri. Univ. P.R. 58 (3): 293-304.

11. Deinum, B. and Van Soest, P. J., 1969. Prediction of forage digestibility from some laboratory procedures, Neth. J. Agri. Sci. 17: 119-27.

12. Devendra, C. and Burns, M., 1970. Goat Production in the Tropics. Commonw. Bur. Anim. Genet., Edinburgh, Tech. Com. 19.

13. Dirven, J. G. P. and Deinum, B., 1977. The effect of temperature on the digestibility of grasses, An analysis, For. Res. 3: 1-17.

14. Gihad, E. A., 1976. Intake, digestibiity and nitrogen utilization of tropical natural grass hay by goats and sheep, J. Anim. Sci. 43: 879-83.

15. Goering, H. K. and Van Soest, P. J., 1970. Forage fiber analyses (apparatus, reagents, procedures and some applications), USDA Agri. Handbook 379.

16. Gutiérrez-Vargas, R., Arroyo-Aguilú, J. A., and Ramírez-Ortiz, A., 1978. Voluntary intake, chemical composition, and nutrient digestibility of Pangolagrass and Stargrass hays, J. Agri. Univ. P.R. 62 (4): 389-98.

17. Jones, G. M., Larsen, R. E., Jared, A. H., Donefer, E., and Gaudreau, J. M., 1972. Voluntary intake and nutrient digestibility of forages by goats and sheep, J. Anim. Sci. 34: 830-8.

18. Lucas, Jr., H. L., Smart, Jr., W. W. G., Cipolloni, M. A., and Gross, H. D., 1961. Relations between digestibility and composition of feeds and foods, S-45 Rept., N.C. State Coll., Raleigh, N.C.

19. Maynard, L. A. and Loosli, J. K., 1969. Animal Nutrition, 6th ed, McGraw-Hill Book Co., Inc., New York, N.Y.

20. Snedecor, G. W. and Cochran, W. G., 1967. Statistical Methods, 6th ed, The Iowa State Univ. Press, Ames, Iowa.

21. Ulyatt, M. J., 1973. The feeding value of herbage, ch. 31, pp. 131-78, in Chemistry and Biochemistry of Herbage, vol. 3, G. W. Butler and R. W. Bailey, Ed.

22. Van Soest, P. J., 1966. Forage intake in relation to chemical composition and digestibility: Some new concepts, Proc. 23rd Southern Past. For. Crop. Imp. Conf., Blacksburg, Va.

23. - 1966. Nonnutritive residues: A system of analysis for the replacement of crude fiber, J. Assoc. Off. Anal. Chem. 49: 546-51.

24. - 1967. Development of a comprehensive system of feed analyses and its application to forages, J. Anim. Sci. 29: 119-28. 